\title{
THE OPINIONS OF EDUCATION FACULTY STUDENTS ABOUT EDUCATIONAL COURSES
}

\author{
Sedat YÜKSEL ${ }^{*}$
}

\begin{abstract}
The students' opinions about educational courses in two education faculties were determined in this study. This research was conducted with the students at the Uludag and Gazi universities. According to results of this study, students have positive opinions about the teaching profession and the instructors teaching these courses and they are aware of the importance of these courses. On the other hand, they have comparatively low level positive opinions about the educational courses. The interpretation of the results was done according to the related literature.
\end{abstract}

Keywords: Teacher education, educational courses, education faculty.

\footnotetext{
*Assist. Prof. Dr., Uludağ University, Faculty of Education, e-mail: sedaty@uludag.edu.tr
} 


\section{SUMMARY}

Purpose and significance: Educational courses are the most important factors to develop students' knowledge, skills, and attitudes related to the teaching profession. However, it is argued that these courses should be eliminated since they are not effective or necessary (Bestor, 1953; Brubacher, 1966; Conant, 1963; Koerner, 1963; Lortie, 1975). Hence, the weight of the educational courses has been lately reduced; the weight of subject-matter courses has been increased due to these negative opinions. For this reason, educational faculties have met with the danger of not preparing professional teachers (Clifford \& Guthrie, 1988; Shen, 1999; Soder \& Sirotnik, 1990). The number of educational courses has been increased with the changes done in Turkish educational system. However, this increase cannot guarantee to prepare qualified teachers. The important point is here that these courses should be effectively given to students. The prerequisite of taking effectively these courses is the attitudes and opinions of students. The purpose of this study is to determine opinions of the students towards educational courses given by the instructors at the department of educational sciences at educational faculties.

Discussion and Conclusions: After connecting teacher education programs to universities in Turkey, the structure of the teaching staff of these teacher education institutions has changed and the teaching staff mostly has come from the liberal art faculties. As a result of this, instead of an professional structure, an academic structure has been established at the educational faculties. In this structure, According to the results of this study, students have have comparatively low level positive opinions about the educational courses although they have positive opinions about the teaching profession and their instructors and they stated that these courses were necessary. In short, the low level positive opinions of the students about these courses are not caused by students' dislike about the teaching profession or the behaviors of the instructors. The reasons for students' low level positive opinions about educational courses needs to be researched in the light of these findings. The reason for these low level positive opinions might be the hidden curriculum in these departments. In this respect, it has been predicted that important results can be obtained by the research revealing the hidden curriculum of faculties and departments. 


\title{
EĞITIM FAKÜLTESİ ÖĞRENCILERININ ÖĞRETMENLİK MESLEK BILGIISİ DERSLERİNE ÍLIŞKIIN GÖRÜŞLERI
}

\begin{abstract}
Sedat YÜKSEL ${ }^{*}$
ÖZ: $\mathrm{Bu}$ araştırmada Eğitim Fakültesi öğrencilerinin öğretmenlik meslek bilgisi (ÖMB) derslerine yönelik görüşleri tespit edilmiştir. Araştırma Uludağ ve Gazi Üniversitesi Eğitim Fakültesi öğrencileri üzerinde yapılmıştır. Araştırmanın sonucunda öğrencilerin öğretmenlik mesleğine ve ÖMB derslerine giren öğretim elemanlarına olumlu baktıkları, ÖMB derslerinin gerekliliğinin farkında oldukları, buna karşılık ÖMB derslerine yönelik düşüncelerinin çok olumlu olmadığı ortaya çıkmıştır. Araştırmada elde edilen sonuçlar ilgili literatüre dayalı olarak yorumlanmıştır.
\end{abstract}

Anahtar Sözcükler: Öğretmen eğitimi, öğretmenlik meslek bilgisi dersleri, eğitim fakültesi.

* Yrd. Doç. Dr., Uludağ Üniversitesi Eğitim Fakültesi e-mail: sedaty@uludag.edu.tr 


\section{GíRiș}

Öğretmen nitelikleri ve öğretmen yetiştirme konusu Türkiye'de her dönem tartışma konusu olmuştur. İlk öğretmen okulunun açıldığı 1848 y1lından günümüze kadar olan dönemde Türk öğretmen yetiştirme sisteminin çağın gereklerine uygun, kaliteli öğretmenler yetiştirebilmesine yönelik çeşitli yenilik ve uygulamalar yapılmıştır. 1739 Sayılı Milli Eğitim Temel Kanunu öğretmenliği özel bir uzmanlık mesleği olarak tanımlamış ve tüm öğretmen adaylarının yükseköğrenim görmeleri gerektiğini karara bağlanmıştır. Öğretmen yetiştirme programları ile ilgili olarak da bu programlarda genel kültür, özel alan eğitimi ve pedagojik formasyon (öğretmenlik meslek bilgisi-ÖMB) derslerinin yer alması gerektiği belirtilmiştir.

Öğrencilerin öğretmenlik mesleğine ilişkin bilgi, beceri ve tutum geliştirmelerinde en önemli faktörlerden birisi, hiç şüphesiz ki ÖMB dersleridir. ÖMB derslerini almamış bir öğretmen adayının alan bilgisini öğretme sürecinde çeşitli zorluklar yaşayacağ 1 kuşkusuzdur. Diğer taraftan bu dersler öğrencinin öğretmenlik mesleğini daha iyi tanımasına ve sevmesine de yardımcı olacaktır. Ancak ÖMB derslerinin programda yer alması nitelikli öğretmen yetiştirmenin garantisi olamaz. Burada önemli olan bu derslerin ögrencilere etkili ve verimli bir şekilde verilerek onlara bir yandan öğretmenlik bilgi ve becerisi kazandırılmasını, diğer yandan mesleğini istek ve şevkle yapabilmesi için kendisinden olumlu yönde tutumlar geliştirmesini sağlamaktır. Ancak ÖMB dersleri ile ilgili olarak, bu derslerin etkili verilemediği, bu derslerin gereksiz olduğu, kaldırılması gerektiği vb. fikirler ileri sürülmektedir. Bu fikirler hem ÖMB derslerine giren öğretim elemanlarını hem de öğretmen adaylarının mesleki gelişimlerini olumsuz etkilemektedir.

EĞİTIM FAKÜLTESİ PROGRAMLARINDA ÖĞRETMENLİK MESLEK BILLGISİ DERSLERİ TARTIŞMASI

Öğretmen eğitimi konusunda yapılan tartışmaların temelinde yeni mezun öğretmenlerin niteliklerindeki yetersizlikler yer almaktadır. Buna bağlı olarak öğretmen eğitimi programlarının yeterliliği konusunda üniversitelerde görevli akademisyenler arasında da çatışmalar yaşanmaktadır. Bazı akademisyenler, öğretmen olabilmek için öğretmen adayın öğreteceği alana ilişkin olarak alan bilgisini çok iyi düzeyde bilmesinin yeterli olduğuna inanmaktadır. Diğer taraftan, bazı akademisyenler de ögretmenlerin daha az yoğunlukta alan bilgisi ve bu konuları nasıl öğreteceğine ilişkin olarak ÖMB dersleri konularında yeterli olmaları gerektiğini savunmaktadır (Cruickshank, 1985). Aslında bu tartışmaların temelinde öğretmen yetiştiren kurumların üniversite içerisinde yer almasının bulunduğu söylenebilir. 
19. yüzyılın son çeyreğinde başlayan ve yoğun bir şekilde devam eden öğretmen eğitimi kurumlarının üniversitelere devredilmesi hareketi bazı sorunları da beraberinde getirmiştir. Üniversitelerdeki akademisyenler yeni kurulan pedagoji kürsülerine karşı çıkmış, bu konuda olumsuz düşünceler ileri sürmüşlerdir. Kendileri eğitim bilimlerini en alt statüdeki bilim dalları arasında görmüşler, hatta eğitimin bir bilim olup olmadığını dahi tartışmışlardır (Shen, 1999; Yang, 1998). Bu olumsuz düşünce ve tutumlar sonucunda üniversite bünyesinde kurulan eğitim fakülteleri üniversite içerisinde düşük statülü sınıf ve üniversite yönetimi tarafindan en az düzeyde desteklenen programlar olmuşlardır. (Clark \& Marker, 1975; Ducharme, 1985; Gideonse, 1984; Howsam, Corrigan, Denemark \& Nash, 1976; Walton, 1964).

Üniversite yönetimlerinin Eğitim Fakültelerine yönelik olumsuz bakışlarının yanında eğitim fakültesinin yapısı, işleyişi ve programları üzerinde yoğun eleştiriler yapılmıştır. Yapılan eleştiriler özellikle ÖMB dersleri hakkında olmuştur. ABD'li bazı akademisyenler (örneğin Bestor, 1953; Brubacher,1966; Conant, 1963; Koerner, 1963; Lortie, 1975) öğretmen adaylarının konu alanı bilgilerinde yetersizlikler olduğunu, öğretmen eğitimi programlarındaki derslerin çoğunun akademik bir içerik taşımadığını ve bu arada ÖMB derslerinin sınırlarının da belirsiz olduğunu, bu nedenle öğrencilerin gerekli bilgi ve beceriden yoksun olarak yetiştiklerini ileri sürmüşlerdir. Bu eleştiriler zamanla daha fazla destek bulmuştur. Özellikle 1980'li yıllarda ABD'de ve İngiltere'de alan bilgisi güçlü öğretmenler yetiştirilmek üzere lisans düzeyinde öğretmen eğitimine son verilerek Fen-Edebiyat Fakültesi mezunlarına lisansüstü eğitim verilmesi ve ÖMB derslerinin ağıllıklarının azaltılarak bunun yerine okulda uygulamalara ağırlık verilmesi vb. talepler yoğunlaşmış ve bu fikirler kısa zamanda üniversitelerde uygulanmaya başlanmıştır. ÖMB dersleri, özellikle de eğitimin temelleri dersleri (eğitim tarihi, eğitim sosyolojisi, eğitim felsefesi vb) öğretmen eğitimi programlarından çıkarılmıştır. Bu talep ve uygulamalardaki temel anlayış öğretmenlik bilgi ve becerisinin bir ders şeklinde verilemeyeceği, bunun ancak okullarda usta-çırak ilişkisi içerisinde öğrenilecek bir meslek olduğudur (Nelson, Palonsky \& Carlson, 1990). ÖMB dersleri aleyhindeki bu görüş ve uygulamalar sonucunda ÖMB derslerinin programlardaki ağıllıkları azaltılmış, konu alanı derslerine daha fazla ağırlık verilmiştir. Böylece Eğitim Fakülteleri mesleki (profesyonel) açıdan güçlü öğretmenler yetiştirememe tehlikesiyle karşı karşıya kalmışlardır (Clifford \& Guthrie, 1988; Shen, 1999; Soder \& Sirotnik, 1990). 


\section{ÜLKEMIZDE ÖĞRETMEN YETIŞTIRME VE ÖĞRETMENLIKK MESLEK BILGISII DERSLERİ}

Ülkemizde son 30 yıldır yapılan reformların önemli bir kısmı öğretmen eğitimi ile ilgilidir. Bu reformlar içerisinde en önemlisi 1981 reformudur. Bu reform ile daha önce Milli Eğitim Bakanlığına bağlı olan öğretmen yetiştiren kurumlar üniversitelere bağlanmıştır. (Binbasığlu, 1995; Küçükahmet, 1993). Bu reformun lehinde veya aleyhinde çeşitli tartışmalar olmakla birlikte, öğretmen eğitiminin üniversitelere devredilmesi genelde olumlu yankılar bulmuştur. $\mathrm{Bu}$ reform ile öğretmen eğitimi politik etkilerden kurtarılarak özerk hale getirilmiş ve öğretmen eğitimi üzerinde yapılan çalışmaların daha akademik ve bilimsel olarak yürütülmesi sağlanmıştır (Duman, 1998). Bu olumlu yönlerine karşılık, öğretmen yetiştirmenin üniversite içerisine alınması çeşitli problemleri de beraberinde getirmiştir. $\mathrm{Bu}$ dönemde görülen problemlerin en önemlisi üniversite bünyesinde yaşanan yapısal problemlerdir. Bu problemler aynı tecrübeyi yaşayan çoğu batılı ülkelerle benzerlik göstermektedir. Öğretmen yetiştirme görevi üniversitelere devredildikten sonra üniversiteler eğitim fakültelerini benimseyememiş, öğretmenlik mesleğini ciddiye almayarak öğretmenliği küçümsemișlerdir (Kavcar, 2002; Okçabol, 2005; Özdemir, 1998; Șişman, 2000). Üniversiteler öğretmen eğitimini tam olarak kavrayamamış, öğrencilerin mesleki yönden gelişmeleri ile genel kültür ve uygulama (staj) faaliyetleri önemsenmemiş, ÖMB dersleri genellikle kalabalık sinıflarda yapılmıştır. Akademik kadrolar ağırlıklı olarak Fen-Edebiyat kökenli oldukları için öğretmenlik mesleğine ilişkin -özellikle- beceri ve duyuşsal özellikler öğrencilere kazandırılamamıştır (Ataman, 1998; Duman, 1991; Okçabol 2005; Önsoy, 1998). Kısacası Üniversiteler içinde öğretmenlik havasının sağlanamadığı anlaşılmaktadır. Bu yapının sonucu olarak, yapılan araştırmalarda da öğretmen adaylarının öğretmenlik meslek bilgisi düzeylerinin zayıf (Özdilek-Kılıç, 1997), öğretmenliğe yönelik tutumlarının da düşük düzeyde olduğu ortaya çıkmıştır (Can, 1987; 1989; Özdilek-Kılıç, 1997; Sözer, 1992).

Öğretmen eğitiminde yaşanan bu sorunlar karşısında 1997 yılında "öğretmen eğitiminde yeniden yapılanma" adıyla yeni bir reform yapılmıştır. Bu reform 1998- 1999 öğretim yılında uygulanmaya başlanmıştır. 1981 reformu ile önemli yapısal değişiklikler yapılırken, bu reform ile özellikle programlar ve uygulamalar yönünden önemli değişiklikler yapılmıştır. $\mathrm{Bu}$ reform ile Eğitim Fakültesi programlarında yer alan konu alanı derslerinin derinliğine ve yoğun öğretimi engellenmiş, ÖMB derslerinin sayısı ve kredilerinde önemli değişiklikler yapılmış, bu dersler içerisinde teorik olanlar, özellikle de eğitimin temelleri dersleri (eğitim tarihi, eğitim felsefesi, eğitim sosyolojisi)- eğitim psikolojisi hariç- programdan 
kaldırılmış ve öğrencilerin okullarda uygulama yapma saatleri artırılmıştır (YÖK, 1997). Bu reform öğretmen eğitimi programlarında sosyoloji, felsefe ve eğitimin temelleri vb. derslerin programlardan çıkararak genel kültür boyutunu göz ardı ettiği (Okçabol, 2005; Yılman \& Dinç, 2000; Bülbül, 1999; Kaptan- Aksu, 2001; Kavcar, 1999) ve programların bu haliyle ögretmen adaylarının öğretmenliğe yönelik duyuşsal tutumlar geliştirmelerini sağlayamayacağı (Kavcar, 1999; Yılman, \& Dinç, 2000) gerekçeleriyle eleştirilmiştir.

Yeniden yapılanma reformu ile öğretmen eğitiminde yaşanan bu sorunların giderilmesine yönelik olarak sekiz yıl sonra Yükseköğretim Kurulu (YÖK) eğitim fakültesi programlarında güncelleme ve değişiklikler yapmaya karar vermiş, bu değişiklikler 2006-2007 öğretim y1lında uygulanmaya başlanmıştır. $\mathrm{Bu}$ reformla eğitim fakültesi programlarının genel kültür boyutunun yetersiz olduğu kabul edilerek öğretmen adayına entellektüel donanım kazandırmak üzere bilim tarihi, felsefeye giriş vb. gibi dersler ile eğitimin temelleri dersleri programlara konulmuş̧tur (YÖK, 2006). $\mathrm{Bu}$ düzenlemelere bakıldığında öğretmen eğitiminde genel kültür ve ÖMB derslerine önem verildiği, ve öğrencide öğretmenlik anlayışının güçlendirilmesine çalışıldığı görülmektedir.

Türk öğretmen yetiştirme sisteminde yapılan değişiklikler incelendiğinde eğitim fakültelerindeki akademik anlayışın mesleki (profesyonel) anlayışa dönüştürülmesine çalışıldığı görülmektedir. $\mathrm{Bu}$ çabalar takdir edilmesi gereken çabalardır. Ancak ÖMB derslerinin ağırlıklarının artırılmaya çalışılması öğretmen adaylarının daha nitelikli yetiştirileceğinin garantisi olamaz. Burada önemli olan bu derslerin etkili ve verimli bir şekilde öğrencilere verilmesidir. Bunun için de ön şart öğrencilerin bu derslere yönelik görüş ve tutumlarıdır. Ancak öğrencilerin ÖMB dersleri hakkındaki görüşlerini ortaya koyan herhangi bir araştırmaya rastlanılamamıştır.

$\mathrm{Bu}$ araştırmada Eğitim Fakültesi öğrencilerinin Eğitim Bilimleri Bölümü öğretim elemanlarınca verilen ÖMB derslerine (öğretmenlik mesleğine giriş, gelişim ve öğrenme, öğretimde plânlama ve değerlendirme, öğretim teknolojileri ve materyal geliştirme, sınıf yönetimi ve rehberlik) iliş̧in görüşlerinin tespit edilmesi amaçlanmıştır. Bu amaç doğrultusunda aşağıdaki sorulara cevap aranacaktır:

1) Eğitim Fakültesi ögrencilerinin ÖMB derslerine ilişkin görüşleri ne düzeydedir?

2) Eğitim Fakültesi öğrencilerinin ÖMB derslerine ilişkin görüşleri öğrenim gördükleri üniversite/fakülte'ye göre farklılık göstermekte midir?

3) Eğitim Fakültesi öğrencilerinin ÖMB derslerine ilişkin görüşleri cinsiyetlerine göre farkl1l1k göstermekte midir?

4) Eğitim Fakültesi öğrencilerinin ÖMB derslerine ilişkin görüşleri branşlarına göre farkl1lık göstermekte midir? 


\section{YÖNTEM}

\section{Model}

$\mathrm{Bu}$ araştırma betimsel bir araştırmadır. Betimsel araştırmalar mevcut olayların daha önceki olay ve koşullarla ilişkilerini dikkate alarak durumlar arasındaki etkileşimi açıklamaya çalışan, olayların, objelerin, varlıkların, kurumların, grupların ve çeşitli alanların ne olduğunu betimleyen araştırmalardır (Kaptan, 1995).

\section{Çalışma Grubu}

Araştırma 2006-2007 öğretim y1lı bahar döneminde Uludağ ve Gazi Üniversitesi Eğitim Fakültelerinin İngilizce, Resim- İş, Bilgisayar ve Öğretim Teknolojileri (BÖTE) ve Rehberlik ve Psikolojik Danışmanlık (RPD) programları son sınıfa kayıtlı 414 öğrenci üzerinde yapılmıştır. Son sınıf öğrencilerinin alınmasının sebebi bu öğrencilerin hem öğretmenlik meslek, hem de alan bilgisi derslerinin hepsini almış olmaları ve bu nedenle daha geçerli bir değerlendirme yapabileceklerinin varsayılmasıdır. Tablo 1 'de çalışma grubu ile ilgili bilgiler verilmektedir.

Tablo 1. Çalıșma Grubu

\begin{tabular}{|c|c|c|c|c|c|c|c|c|c|c|c|c|}
\hline \multirow[b]{4}{*}{ Branş } & \multicolumn{12}{|c|}{ Üniversite/ Fakülte Ad1 } \\
\hline & \multicolumn{6}{|c|}{ Uludağ Üniv. Eğitim Fak } & \multicolumn{6}{|c|}{ Gazi Üniv. Eğitim Fak. } \\
\hline & \multicolumn{2}{|c|}{$\mathrm{KIZ}$} & \multicolumn{2}{|c|}{ ERKEK } & \multicolumn{2}{|c|}{ TOPLAM } & \multicolumn{2}{|c|}{ KIZ } & \multicolumn{2}{|c|}{ ERKEK } & \multicolumn{2}{|c|}{ TOPLAM } \\
\hline & $\mathrm{n}$ & $\%$ & $\mathrm{n}$ & $\%$ & $\mathrm{n}$ & $\%$ & $\mathrm{n}$ & $\%$ & $\mathrm{n}$ & $\%$ & $\mathrm{n}$ & $\%$ \\
\hline $\begin{array}{l}\text { İngilizce } \\
\text { Öğretm. }\end{array}$ & 65 & 86,7 & 10 & 13,3 & 75 & 32,8 & 61 & 88,4 & 8 & 11,6 & 69 & 37,3 \\
\hline $\begin{array}{l}\text { Resim- İş } \\
\text { Öğretm. }\end{array}$ & 58 & 78,4 & 16 & 21,6 & 74 & 32,2 & 31 & 70,5 & 13 & 29,5 & 44 & 23,8 \\
\hline BÖTE & 16 & 35,6 & 29 & 64,4 & 45 & 19,7 & 11 & 34,4 & 21 & 65,6 & 32 & 17,3 \\
\hline RPD & 18 & 51,4 & 17 & 48,6 & 35 & 15,3 & 26 & 69,7 & 14 & 30,3 & 40 & 21,6 \\
\hline Toplam & 157 & 68,6 & 72 & 31,4 & 229 & 100,0 & 129 & 69,7 & 56 & 30,3 & 185 & 100,0 \\
\hline $\begin{array}{l}\text { Gen. Top. } \\
\text { (UÜ+ GÜ) }\end{array}$ & 157 & 37,9 & 72 & 17,4 & 229 & 55,3 & 129 & 31,2 & 56 & 13,5 & 185 & 44,7 \\
\hline
\end{tabular}

Tablo 1'de görüldüğü gibi araştırmaya katılan öğrencilerin \% 55. 3’ü Uludağ Üniversitesi (UÜ), \% 44.7'si Gazi Üniversitesi (GÜ) Eğitim Fakültesi öğrencisi olup, tüm öğrencilerin \% 69.1'i kız \%30.9'u erkektir. Öğrencilerin kayıtlı oldukları programlar incelendiğinde ise İngilizce ve Resim- İş Eğitimi programlarının ağılıklı olarak kız öğrencilerden, buna karşılık BÖTE programının ağırlıklı olarak erkek öğrencilerden oluştuğu görülmektedir. RPD programı ile ilgili olarak GÜ'de kıların ağırlıklı olduğu, buna karşılık UÜ'de kız ve erkeklerin hemen hemen eşit oldukları görülmektedir. 


\section{Veri Toplama Aracı}

Araştırmada öğrencilere araştırmacı tarafından geliştirilen Öğretmenlik Meslek Bilgisi Dersleri Ölçeği (ÖMBÖ) uygulanmıştır. Ölçek beşli Likert tipi bir ölçektir. Ölçeğin seçenekleri ve puanlaması; Kesinlikle Katılırım 5, Katılırım 4, Kararsızım 3, Katılmam 2, Kesinlikle Katılmam 1 şeklindedir. Olumsuz ifadeli veya olumsuz yönde fikir içeren maddelerde puanlama ters yönde işleyecek şekilde 1,2,3,4,5 olarak yapılmıştır.

Ölçeğin geliştirilmesi aşamasında ilk olarak ÖMB dersleri ve öğretmenlik mesleği ile ilgili yapılan çalışma ve araştırmalar incelenmiş, bu derslere giren öğretim elemanları ve öğrencilerle görüşmeler yapılmıştır. Bu çalışmaların sonucunda pilot uygulaması yapılmak üzere 54 maddelik bir araç hazırlanmıştır. Bu araç 181 öğrenci üzerinde uygulanmış, sonuçlar üzerinde geçerlik ve güvenirlik işlemleri yapılmıştır.

Ölçeğin güvenirliği ile ilgili olarak yapılan işlemlerde ilk olarak ölçekte yer alan soruların bütün bir ölçek oluşturacak şekilde hazırlanıp hazırlanmadığı, sorulardan elde edilen puanların toplanabilir olup olmadığını belirlemek üzere ölçeğin toplanabilirlik özelliği test edilmiştir (Özdamar, 2004). Yapılan "Tukey Non-Additivity" testi sonucunda ölçeğin toplanabilir özelliğinin olduğu belirlenmiştir (Friedman $\mathrm{x}^{2}=38.47 ; \quad \mathrm{p}=<, 001$ ). Elde edilen bu sonuç doğrultusunda ölçeğin güvenirlik analizi yapılmıştır. Tablo 2 ÖMBÖ ölçeğinin güvenirlik analizi sonuçlarını vermektedir.

\section{Tablo 2. ÖMBÖ Ölçeği Güvenirlik Analizi Sonuçları}

\begin{tabular}{|c|c|c|c|c|c|c|c|c|}
\hline $\begin{array}{l}\text { Madde } \\
\text { No } \\
1-18\end{array}$ & $\begin{array}{l}\text { Madde } \\
\text { Toplam } \\
\text { Korelasyon } \\
\text { Katsayıları }\end{array}$ & $\begin{array}{l}\text { Madde İç } \\
\text { Tutarlılık } \\
\text { Değişikliği }\end{array}$ & $\begin{array}{l}\text { Madde } \\
\text { No } \\
19-36\end{array}$ & $\begin{array}{l}\text { Madde } \\
\text { Toplam } \\
\text { Korelasyon } \\
\text { Katsayıları }\end{array}$ & $\begin{array}{l}\text { Madde İç } \\
\text { Tutarlı1ık } \\
\text { Değişikliği }\end{array}$ & $\begin{array}{l}\text { Madde } \\
\text { No } \\
37-54\end{array}$ & $\begin{array}{l}\text { Madde } \\
\text { Toplam } \\
\text { Korelasyon } \\
\text { Katsayıları }\end{array}$ & $\begin{array}{l}\text { Madde } \\
\text { İç } \\
\text { Tutarlılık } \\
\text { Değişikliği }\end{array}$ \\
\hline 1 & .65 & ,94 & 19 & .66 & ,94 & 37 & .55 &, 94 \\
\hline 2 & .66 & ,94 & 20 & .65 &, 94 & 38 & .40 & ,94 \\
\hline 3 & .62 & ,94 & 21 & .73 &, 94 & 39 & .42 &, 94 \\
\hline 4 & .55 &, 94 & 22 & .30 & ,94 & 40 & .48 &, 94 \\
\hline 5 & .60 &, 94 & 23 & .48 & ,94 & 41 & .43 &, 94 \\
\hline 6 & .56 & ,94 & 24 & .53 &, 94 & 42 & .23 & ,94 \\
\hline 7 & .45 & ,94 & 25 & .72 & ,94 & 43 & .39 &, 94 \\
\hline 8 & .54 &, 94 & 26 & .45 & ,94 & 44 & .37 &, 94 \\
\hline 9 & .37 & ,94 & 27 & .41 &, 94 & 45 & .40 &, 94 \\
\hline 10 & .68 & ,94 & 28 & .56 & ,94 & 46 & .24 &, 94 \\
\hline 11 & .60 & ,94 & 29 & .19 & ,94 & 47 & .19 &, 94 \\
\hline 12 & .27 & ,94 & 30 & .49 &, 94 & 48 & .39 &, 94 \\
\hline 13 & .67 &, 94 & 31 & .52 &, 94 & 49 & .37 & 94 \\
\hline 14 & .62 & ,94 & 32 & .55 & ,94 & 50 & .43 & ,94 \\
\hline 15 & .64 & ,94 & 33 & .34 &, 94 & 51 & .45 &, 94 \\
\hline 16 & .64 & ,94 & 34 & .42 &, 94 & 52 & .37 &, 94 \\
\hline 17 & .43 & ,94 & 35 & .34 &, 94 & 53 & .30 &, 94 \\
\hline 18 &, 30 & ,94 & 36 & .62 & ,94 & 54 & .27 & ,94 \\
\hline
\end{tabular}


Tablo 2' de görüldüğ̈̈ gibi ölçekte $12,18,22,29,42,46,53$ ve 54 . maddelerin Madde Toplam Korelasyon Katsayıs1 .30 ve altı değerde çıktığından ölçekten atılması düşünülmüştür (Büyüköztürk, 2005). Ancak bu maddelerin Madde İç Tutarlılık Değişikliği Derecesinin yüksek çıkması, yani bu maddelerin araçtan çıkarılması halinde ölçeğin güvenirliğinin çok düşmemesi nedeniyle, bu maddelerin araçtan çıkarılıp çıkarılmama kararı faktör analizi sonrasına bırakılmıştır.

Ölçeğin yapı geçerliğini belirlemek üzere Temel Bileşenler Analizi (Principal Components) üzerinde temellenen faktör analizi işlemleri yapılmış, rotasyon yöntemi olarak varimax rotation kullanılmıştır. Analiz sonucunda güvenirlik çalışması esnasında madde toplam korelasyon katsayısı düşük çıkan maddelerin aynı zamanda faktör yüklerinin de düşük çıkması (faktör yükü .40 in altında) nedeniyle araçtan çıkarılmalarına karar verilmiştir. Bu maddelerin yanı sıra 17. (faktör yükü .29) ve 48. (faktör yükü .34) maddeler de faktör yükünün düşük olması nedeniyle araçtan çıkarılmıştır. Ayrıca 52. maddenin faktör yükünün üç ayrı faktöre dağıldığı görülmüş, maddenin incelenmesi sonucunda, Madde Toplam Korelasyon Katsayısının da düşük bir değer almış olması (.37) da göz önüne alınarak bu maddenin de ölçekten çıkarılmasına karar verilmiştir. Söz konusu maddeler çıkarıldıktan sonra yapılan güvenirlik analizinde ölçeğin Cronbach alpha değeri .94 olduğu belirlenmiştir. Bu sonuç ölçeğin yüksek derecede güvenilir olduğunu göstermektedir (Özdamar, 2004). Bu aşamada faktör analizi tekrar yapılmış, ortaya çıkan sonuçlar Tablo 3 de verilmiştir.

Tablo 3. ÖMBÖ Ölçeği Faktör Yapısı

\begin{tabular}{|c|c|c|c|c|c|c|c|c|c|c|c|}
\hline \multicolumn{12}{|c|}{ Faktörler } \\
\hline \multicolumn{3}{|c|}{ F1- ÖMB DERSLERİ } & \multicolumn{3}{|c|}{ F2- ÖĞRETMENLİK MESLEĞİ } & \multicolumn{3}{|c|}{$\begin{array}{c}\text { F3-ÖMB ÖĞRETIM } \\
\text { ELEMANLARI } \\
\end{array}$} & \multicolumn{3}{|c|}{$\begin{array}{l}\text { F4- ÖMB DERSLERİNIN } \\
\text { GEREKLİLIĞİ }\end{array}$} \\
\hline $\begin{array}{l}\text { Madde } \\
\text { No }\end{array}$ & $\begin{array}{l}\text { Faktör } \\
\text { Yükü }\end{array}$ & $\begin{array}{l}\text { Açıkladığ } 1 \\
\text { Varyans }\end{array}$ & $\begin{array}{l}\text { Madde } \\
\text { No }\end{array}$ & $\begin{array}{l}\text { Faktör } \\
\text { Yükü }\end{array}$ & $\begin{array}{l}\text { Açıkladığ } 1 \\
\text { Varyans }\end{array}$ & $\begin{array}{l}\text { Madde } \\
\text { No }\end{array}$ & $\begin{array}{l}\text { Faktör } \\
\text { Yükü }\end{array}$ & $\begin{array}{c}\text { Açıladığı } \\
\text { Varyans }\end{array}$ & $\begin{array}{l}\text { Madde } \\
\text { No }\end{array}$ & $\begin{array}{c}\text { Faktör } \\
\text { Yükü }\end{array}$ & $\begin{array}{l}\text { Açıkladığı } \\
\text { Varyans }\end{array}$ \\
\hline 2 & .80 & 21,69 & 28 & .82 & 12,73 & 41 & .73 & 11,55 & 51 & .70 & 4,63 \\
\hline 10 & .78 & & 32 & .78 & & 43 & .73 & & 50 & .68 & \\
\hline 11 & .77 & & 30 & .76 & & 39 & .72 & & 49 & .60 & \\
\hline 1 & .76 & & 34 & .74 & & 44 & .71 & & & & \\
\hline 15 & .75 & & 31 & .71 & & 37 & .70 & & & & \\
\hline 3 & .72 & & 27 & .70 & & 40 & .68 & & & & \\
\hline 5 & .72 & & 26 & .68 & & 38 & .62 & & & & \\
\hline 4 & .71 & & 33 & .66 & & 36 & .59 & & & & \\
\hline 13 & .71 & & 35 & .57 & & 45 & .42 & & & & \\
\hline 14 & .71 & & & & & & & & & & \\
\hline 8 & .69 & & & & & & & & & & \\
\hline 19 & .69 & & & & & & & & & & \\
\hline 25 & .69 & & & & & & & & & & \\
\hline 21 & .63 & & & & & & & & & & \\
\hline 6 & .61 & & & & & & & & & & \\
\hline 16 & .58 & & & & & & & & & & \\
\hline 20 & .54 & & & & & & & & & & \\
\hline 24 & .52 & & & & & & & & & & \\
\hline 23 & .49 & & & & & & & & & & \\
\hline 9 & .46 & & & & & & & & & & \\
\hline 7 & .44 & & & & & & & & & & \\
\hline Ölçeğin & ünün a & adığı toplan & yans: & & & & & & & & \\
\hline
\end{tabular}


Tablo 3'de yer alan sonuçlardan da anlaşılabileceği gibi yapılan işlemler sonucunda dört faktörlü, 42 maddeden oluşan bir ölçek meydana getirilmiştir. $\mathrm{Bu}$ ölçek Eğitim Fakültesi öğrencilerinin ÖMB derslerine yönelik düşüncelerini belirlemek üzere araştırmanın çalışma grubunda yer alan öğrencilere uygulanmış ve sonuçları üzerinde analizler yapılmıştır.

\section{Verilerin Çözümlenmesi}

Toplanan veriler üzerinde yapılan ilk incelemede, verilerin dağılımına bakılmış, dağılımın normal olup olmadığını belirlemek üzere Toplanan dağılımın basıklık (kurtosis) ve çarpıklık (skewness) değerleri incelenmiş, ayrıca Kolmogorov-Smirnov Testi yapılmıştır. Bu testin anlamlı çıkması nedeniyle $(p=, 000)$ verilerin normal dağ $11 \mathrm{~lm}$ göstermediği, yani nonparametrik olduğu belirlenmiştir. Bu doğrultuda bölümlerarası farkın test edilmesi için Kruskal-Wallis (değişken sayısı ikiden fazla olduğu için), cinsiyet ve üniversiteler arası farkın test edilmesi için de Mann Whitney-U testi (değişken sayısı iki olduğu için) kullanılmıştır. Ayrıca Kruskal-Wallis testinde farkın anlamlı çıkması durumunda farklılığın hangi gruplar arasında olduğunu tespit etmek amaciyla da Mann Whitney-U testi uygulanmıştır. $\mathrm{Bu}$ araştırmada anlamlılık düzeyi .05 olarak kabul edilmiştir.

\section{BULGULAR}

Araştırmada elde edilen bulgular dört başlık altında verilmektedir.

\section{Öğrencilerin ÖMB Dersleri Hakkındaki Görüşsleri}

Araştırmaya katılan öğrencilerin ÖMB derslerine yönelik görüşleri Tablo 4 de verilmektedir.

Tablo 4. Öğrencilerin ÖMB Derslerine Yönelik Görüşlerine İlişskin Betimsel Değerler

\begin{tabular}{lcc}
\hline ÖLÇEK VE ALT BOYUTLAR & Ort & S \\
\hline ÖMBÖ- GENEL ÖLÇEK & 3,50 & 0,62 \\
\hline F1. ÖMB DERSLERİ & 3,36 & 0,78 \\
\hline F2. ÖĞRETMENLIK MESLEĞİ & 3,83 & 2,64 \\
\hline F3. ÖMB ÖĞRETIMM ELEMANLARI & 3,43 & 0,73 \\
\hline F4. ÖMB DERSLERINININ GEREKLILİĞİ & 3,69 & 0,91 \\
\hline
\end{tabular}

Tablo 4'deki betimsel değerler incelendiğinde öğrencilerin ÖMB derslerine yönelik düşüncelerinin "katılırım" düzeyinde olduğu görülmektedir. Ancak ölçeğin alt boyutlarına bakıldığında öğrenciler ÖMB dersleri hakkındaki düşünceleri "kararsızım" düzeyine inmektedir. Bu sonuçlar ışığında öğrencilerin ÖMB derslerine daha olumsuz baktıkları, buna 
karşı1lı bu derslere giren öğretim elemanları ve bu derslerin gerekliliği ile öğretmenlik mesleğine daha olumlu baktıkları söylenebilir.

\section{Üniversite/ Fakültelerine Göre Öğrencilerin ÖMB Dersleri Hakkındaki Görüşleri}

Öğrencilerin kayıtlı oldukları üniversite ve fakültelere göre (UÜ ve GÜ Eğitim Fakülteleri) ÖMB derslerine ilişkin görüşleri tablo $5^{`} \mathrm{de}$ verilmektedir.

Tablo 5. Üniversite ve Fakültelerine Göre Öğrencilerin ÖMB Dersleri Hakkındaki Görüşleri

\begin{tabular}{|c|c|c|c|c|}
\hline & & Sira & & \\
\hline CINSIYET & $\mathrm{n}$ & Ort. & $\mathrm{U}$ & $\mathrm{p}$ \\
\hline \multicolumn{5}{|c|}{ ÖMBÖ- GENEL ÖLÇEK } \\
\hline U. Ü. & 229 & 219,37 & 18464,00 & ,025* \\
\hline G. $\ddot{U}$ & 185 & 192,81 & & \\
\hline \multicolumn{5}{|c|}{ F1. ÖMB DERSLERİ } \\
\hline U. Ü. & 229 & 217,75 & 18835,50 & ,052 \\
\hline G. Ü & 185 & 194,81 & & \\
\hline \multicolumn{5}{|c|}{ F2. ÖĞRETMENLİK MESLEĞİ } \\
\hline U. Ü. & 229 & 214,46 & 19588,00 & ,187 \\
\hline G. Ü & 185 & 198,88 & & \\
\hline \multicolumn{5}{|c|}{ F3. ÖMB ÖĞRETIMM ELEMANLARI } \\
\hline U. Ü. & 229 & 222,65 & 17713,00 & ,004* \\
\hline G. Ü & 185 & 188,75 & & \\
\hline \multicolumn{5}{|c|}{ F4. ÖMB DERSLERİNIN GEREKLİLİĞİ } \\
\hline U. Ü. & 229 & 207,49 & 21181,00 & ,999 \\
\hline G. Ü & 185 & 207,51 & & \\
\hline
\end{tabular}

Tablo 5 incelendiğinde ÖMB derslerine yönelik düşüncelerde Uludağ Üniversitesi Eğitim Fakültesi öğrencilerinin görüşlerinin Gazi Üniversitesi Eğitim Fakültesi öğrencilerinin görüşlerine göre daha olumlu olduğu görülmektedir. Buna karşılık ölçeğin diğer alt boyutlarında anlamlı bir fark tespit edilememiştir. Sadece ÖMB derslerine giren öğretim elemanları boyutunda UÜ öğrencileri lehine anlamlı bir fark tespit edilmiştir. Bu sonuç UÜ öğrencilerinin ÖMB derslerine daha olumlu bakmasında derslerin içeriğinden ziyade, büyük ölçüde bu derslere giren öğretim elemanlarının etkisi olduğunu ortaya koymaktadır. 


\section{Cinsiyetlerine Göre öğrencilerin ÖMB Dersleri Hakkındaki Görüşleri}

Öğrencilerin cinsiyetleri dikkate alınarak yapılan analizlerin sonuçları Tablo 6'da yer almaktadır.

Tablo 6. Cinsiyetlerine Göre öğrencilerin ÖMB Dersleri Hakkındaki Görüşleri

\begin{tabular}{|c|c|c|c|c|}
\hline CINSIYET & $\mathrm{n}$ & $\begin{array}{l}\text { Sira } \\
\text { Ort. }\end{array}$ & $\mathrm{U}$ & $\mathrm{p}$ \\
\hline \multicolumn{5}{|c|}{ ÖMBÖ- GENEL ÖLÇEK } \\
\hline K1Z & 286 & 229,80 & 11640,00 & ,000* \\
\hline Erkek & 128 & 155,65 & & \\
\hline \multicolumn{5}{|c|}{ F1. ÖMB DERSLERİ } \\
\hline $\mathrm{K} 1 \mathrm{Z}$ & 286 & 226,88 & 12476,50 &, $000^{*}$ \\
\hline Erkek & 128 & 162,24 & & \\
\hline \multicolumn{5}{|c|}{ F2. ÖĞRETMENLİK MESLEĞİ } \\
\hline $\mathrm{K} 1 \mathrm{Z}$ & 286 & 229,34 & 11723,00 &, $000 *$ \\
\hline Erkek & 128 & 156,70 & & \\
\hline \multicolumn{5}{|c|}{ F3. ÖMB ÖĞRETİM ELEMANLARI } \\
\hline K1Z & 286 & 218,77 & 14794,00 &, $003 *$ \\
\hline Erkek & 128 & 180,49 & & \\
\hline \multicolumn{5}{|c|}{ F4. ÖMB DERSLERİNIN GEREKLİLIĞİ } \\
\hline $\mathrm{K} 1 \mathrm{Z}$ & 286 & 214,80 & 15931,50 &, $045^{*}$ \\
\hline Erkek & 128 & 189,44 & & \\
\hline
\end{tabular}

Tablo 6 incelendiğinde görülebileceği gibi kı öğrenciler ÖMB derslerine yönelik daha olumlu düşüncelere sahiptir. Bu durum ölçeğin bütün alt boyutlarına da aynen yansımaktadır. Ortaya çıkan bu bulgu kız öğrencilerinin ÖMB derslerine daha olumlu baktıklarını (Yüksel, 2004b) ve öğretmenlik tutumlarının daha olumlu olduğunu (Aşkar \& Çelenk, 1989; Okçabol, et. al, 2003; Saracaloğlu, 1991, 1992; Seferoğlu, 2004; Tanrı̈ğen, 1997) ortaya koyan araştırmaların sonuçlarını desteklemektedir. Buna karş1lık literatürde kız ve erkek öğrenciler arasında fark bulunamayan araştırmaların da bulunduğu unutulmamalıdır (Erden, 1995; Kaplan \& İpek, 2002; Saracaloğlu et. al, 2004).

\section{Branşlarına Göre Öğrencilerin ÖMB Dersleri Hakkındaki Görüş̧leri}

Öğrencilerin öğrenim gördükleri branşlara göre ÖMB dersleri hakkındaki görüşlerine ilişkin olarak yapılan analizlerin sonuçları Tablo 7'de yer almaktadır. 
Tablo 7. Branşlarına Göre öğrencilerin ÖMB Dersleri Hakkındaki Görüşleri

\begin{tabular}{|c|c|c|c|c|c|c|}
\hline Branş & $\mathrm{n}$ & Sira Ort. & $\mathrm{Sd}$ & $\mathrm{x}^{2}$ & $\mathrm{p}$ & $\begin{array}{l}\text { Anlaml1 } \\
\text { Fark }\end{array}$ \\
\hline \multicolumn{7}{|c|}{ ÖMBÖ- GENEL ÖLÇEK } \\
\hline 1) Resim- İş Eğt. & 118 & 231,83 & 3 & 31,02 & $000^{*}$ & $1-2$ \\
\hline 2) ВÖTE & 77 & 162,18 & & & & $1-3$ \\
\hline 3) RPD & 75 & 166.99 & & & & $4-2$ \\
\hline 4) İngilizce Öğr. & 144 & 232,90 & & & & $4-3$ \\
\hline \multicolumn{7}{|c|}{ F1. ÖMB DERSLERİ } \\
\hline 1) Resim- İș Eğt. & 118 & 220,39 & 3 & 22,53 &, $000 *$ & $1-2$ \\
\hline 2) ВÖTE & 77 & 180,81 & & & & $1-3$ \\
\hline 3) RPD & 75 & 163,44 & & & & $4-2$ \\
\hline 4) İngilizce Öğr. & 144 & 234,16 & & & & $4-3$ \\
\hline \multicolumn{7}{|c|}{ F2. ÖĞRETMENLİK MESLEĞİ } \\
\hline 1) Resim- İş Eğt. & 118 & 235,78 & 3 & 25,58 &, $000^{*}$ & $1-2$ \\
\hline 2) ВÖTE & 77 & 163,22 & & & & $1-3$ \\
\hline 3) RPD & 75 & 175,38 & & & & $4-2$ \\
\hline 4) İngilizce Öğr. & 144 & 224,73 & & & & $4-3$ \\
\hline \multicolumn{7}{|c|}{ F3. ÖMB ÖĞRETİM ELEMANLARI } \\
\hline 1) Resim- İş Eğt. & 118 & 234,97 & 3 & 25,61 &, $000^{*}$ & $1-2$ \\
\hline 2) ВÖTE & 77 & 148,88 & & & & $3-2$ \\
\hline 3) RPD & 75 & 206,90 & & & & $4-2$ \\
\hline 4) İngilizce Öğr. & 144 & 216,65 & & & & \\
\hline \multicolumn{7}{|c|}{ F4. ÖMB DERSLERININ GEREKLİLIĞİ } \\
\hline 1) Resim- İș Eğt. & 118 & 214,91 & 3 & 7,04 & ,071 & \\
\hline 2) ВÖTE & 77 & 195,51 & & & & \\
\hline 3) RPD & 75 & 180,91 & & & & \\
\hline 4) İngilizce Öğr. & 144 & 221,69 & & & & \\
\hline
\end{tabular}

$* \mathrm{p}<, 05$

Öğrencilerin öğrenim gördükleri branşlara göre ÖMB dersleri hakkındaki görüşlerine bakıldığında ölçekte ve ölçeğin ÖMB derslerinin gerekliliği alt boyutu hariç, tüm alt boyutlarda anlamlı farklılıklar ortaya çıktığı görülmektedir. Farklılığın hangi branşlar arasında olduğunu belirlemek üzere Mann-Whitney U testi ile ikili karşılaştırmalar yapılmışıtır. Buna göre resim-iş ve İngilizce öğretmenliği öğrencilerinin ÖMB derslerine daha olumlu baktıkları, buna karşı1ık RPD ve BÖTE öğrencilerinin daha olumsuz baktıkları ortaya çıkmıştır. Aynı durum ÖMB dersleri ve öğretmenlik mesleği alt boyutlarında da belirlenmiştir. ÖMB derslerine giren öğretim elemanları boyutunda ise resim-iş ve İngilizce öğretmenliğine ilaveten RPD öğrencilerinin BÖTE öğrencilerinden daha olumlu oldukları görülmektedir. Elde edilen bu bulgular RPD öğrencilerinin ÖMB derslerine olumsuz baktıklarını (Yüksel, 2004a), BÖTE öğrencilerinin ise öğretmenlik mesleğine ilişkin tutumlarının düşük olduğunu (Seferoğlu, 2004) belirleyen araştırmaları desteklemektedir. 


\section{SONUÇ VE TARTIŞMA}

Öğretmenlerin nitelikleri her zaman dikkati çeken bir sorun olup, bu sorun doğrultusunda öğretmen eğitimi daima tartışılan bir konu olmuştur. Öğretmenlerde olması gereken alan bilgisi ile öğretmenlik bilgi ve beceri seviyeleri konusunda çeşitli fikirler ileri sürülmüştür. Bu tartışmalar ışığında Türkiye'de öğretmen eğitiminde 1981 den günümüze kadar üç reform yapılmıştır. En önemli değişiklik 1981 reformu ile öğretmen eğitiminin sorumluluğunun Milli Eğitim Bakanlığından alınarak Üniversitelere verilmesi olmuştur. Öğretmen eğitiminin üniversite kampusu içerisine alınmasıyla birlikte, öğretmen eğitimi daha özer bir hale gelmiştir. Ancak daha önce ifade edildiği gibi, öğretmen eğitimi kurumlarının üniversitelere alınması ile birlikte öğretmenlerin konu alanı bilgisi yönünden gelişmelerine ağırlık verildiği görülmektedir. $\mathrm{Bu}$ doğrultuda eğitim fakültelerinin programlarına yoğun içerikli alan bilgisi dersleri yer almıştır. Böylece Eğitim Fakültelerinde mesleki -profesyonel- bir yap1 yerine üniversitenin diğer fakültelerindeki gibi akademik bir yapı oluşmuştur. $\mathrm{Bu}$ durum öğretmen adaylarının mesleğinde kullanacağından çok fazla alan bilgisi edinmesini sağlamıştır. Bunu gidermek üzere yapılan eğitim Fakültelerinin Yeniden Yapılandırılması ile ÖMB dersleri ve öğretmenliğe ilişkin uygulamaların sayı ve kredileri artırılmıştır. Ancak burada sorun, sadece bu yeniliklerin yapılarak sorunların giderileceğinin düşünülmesidir. Ancak yeni programların nasıl uygulanacağı veya amaçlanan şekilde uygulanabilirliği sorgulanamamaktadır. $\mathrm{Bu}$ açıdan ÖMB derslerinin etkili ve verimli bir şekilde işlenip işlenmediğinin ortaya çıkarılması önem kazanmaktadır.

ÖMB dersleri hakkında eğitim fakültesi öğrencilerinin görüşlerini tespit etmeyi amaçlayan bu araştırmada öğrencilerin öğretmenlik mesleğine ve ÖMB derslerine giren öğretim elemanlarına olumlu baktıkları, ÖMB derslerinin gerekliliğinin farkında oldukları belirlenmesine rağmen, öğrencilerin ÖMB derslerine yönelik düşünceleri "kararsızım" düzeyine inmektedir. Bu sonuçlara göre eğitim fakültesi öğrencilerinin öğretmenlik mesleğine ve ÖMB derslerine giren öğretim elemanlarına yönelik olumsuz düşünceler taşımadığı, ancak ÖMB derslerine ilişkin düşüncelerinde sorun olduğu söylenebilir. $\mathrm{Bu}$ bulgudan hareket ederek öğrencilerin ÖMB derslerine yönelik olumsuz düşüncelerinin sebeplerini tespit edecek araştırmalara ihtiyaç duyulmaktadır. Bu sebeplerin başında fakülte ve bölümlerin örtük programları olabilir. Bu açıdan fakülte ve bölümlerin örtük programlarını ortaya çıkaracak araştırmalarda önemli sonuçlara ulaşılabileceği tahmin edilmektedir. 


\section{KAYNAKLAR}

Aşkar, P. \& Çelenk, S. (1989) İlkokula öğretmen yetiştiren Eğitim Yüksekokulu öğrencilerinin öğretmenlik mesleğine ilișkin tutumları konusunda yapılan bir araştırma. Çağdaş Eğitim. 141, 236-141

Ataman, A. (1998) Eğitim Fakültelerinin yeniden yapılandırılmasının düşündürdükleri. Kuram ve Uygulamada Eğitim Yönetimi. 4, 263- 270.

Bestor, A. (1953) Educational wastelands. Urbana, IL: University of Illinois Press.

Binbaşıŏlu, C. (1993) Türkiye'de eğitim bilimleri tarihi. İstanbul: Milli Eğitim Yay.

Brubacher, J. S. (1966) A history of the problems of education. 2. Edition. New York: McGraw-Hill Book Company.

Bülbül, S. (1999) Öğretmen yetiştirmede yeniden yapılanma. 21. Yüzyılın Eşiğinde Türk Eğitim Sistemi Ulusal Sempozyumu (pp. 252-256). Ankara: Tekışık

Büyüköztürk, Ş. (2005) Sosyal bilimler için veri analizi el kitabı. Gözden geçirilmiş 5. Baskı. Ankara: Pegem.

Can, G. (1987) Öğretmenlik meslek anlayıșı üzerine bir araştırma (Ankara okullarında). Anadolu Üniversitesi Eğitim Fakültesi Dergisi 2, 159-170

Can, G. (1989) Öğretmen adaylarının öğrencilere yönelik tutumları. Eskişehir: Anadolu Üniversitesi Yay.

Clark, D. L. \& Marker, G. (1975) The institutionalization of teacher education. Teacher education (74th yearbook of the national Society for the study of education) In K. Ryan (Ed.) (pp.53-86) Chicago: University of Chicago Press.

Clifford, G. J. \& Guthrie, J. W. (1988) Ed school. Chicago: University of Chicago Press.

Conant, J. B. (1963) The education of American teachers. New York: McGraw- Hill.

Cruickshank, D. R. (1985) Models for the preparation of America's teacher. The Phi Delta Kappa Education Foundation. Bloomington, Indiana

Duman, T. (1991) Türkiye'de ortaöğretime öğretmen yetiştirme. İstanbul: Milli Eğitim Basımevi. 
Duman, T. (1998) Cumhuriyetimizin 75. yılında öğretmen yetiştirme sistemimiz ve sorunları. Milli Eğitim 139, 36-43

Ducharme, E. R. (1985) Establishing the place of teacher education in the university. Journal of Teacher Education. 36, 8-11

Erden, M. (1995) Öğretmen adaylarının öğretmenlik sertifika derslerine yönelik tutumları. Hacettepe Üniversitesi Eğitim Fakültesi Dergisi, 11, 99-104.

Gideonse, H. D. (1984) A future role for liberal arts colleges in the preparation of teachers. In A. Tom (Ed.) Teacher education in liberal arts settings (pp.1-12) Washington DC: American Association of Colleges for Teacher Education

Howsam, R., Corrigan, D., Denemark, G., \& Nash, R. (1976). Educating a profession. Washington, DC: American Association of Colleges for Teacher Education.

Koerner, J. (1963) The miseducation of American teachers. Boston: Houghton Mifflin.

Kaplan, A. \& İpek, A. S. (2002) Matematik öğretmenliği adaylarının öğretmenlik mesleğine yönelik tutumlarının incelenmesi. Eğitim ve Bilim 27, 125,69-73

Kaptan, S. (1995) Bilimsel araştırma ve istatistik teknikleri. (Onuncu Bask1). Ankara: Rehber Yayınevi.

Kaptan- Aksu Z. (2001) "Eğitim Fakültelerinin yeniden yapılanması konusunda eğitim fakültelerinde görevli öğretim elemanlarının görüşleri”. Yayınlanmamış Yüksek lisans Tezi. Abant İzzet Baysal Üniversitesi, Sosyal Bilimler Enstitüsü, Bolu

Kavcar, C. (1999) Nitelikli öğretmen sorunu. 21. yüzyılın eşiğinde türk eğitim sistemi ulusal sempozyum. (pp. 267-279). Ankara: Tekış1k

Kavcar, C. (2002) Cumhuriyet döneminde dal öğretmeni yetiştirme. Ankara Üniversitesi Ĕ̈itim Bilimleri Dergisi 35, 1-14

Küçükahmet, L. (1993) Öğretmen yetiştirme (programları ve uygulamaları) Ankara. Gazi Üniversitesi Yay.

Lortie, D. (1975) Schoolteacher: A sociological study. Chicago: University of Chicago Press.

Nelson, J. L.; Palonsky, S. B. \& Carlson, K. (1990) Critical issues in education. New York: McGraw- Hill. 
Okçabol, R. (2005) Öğretmen yetiştirme sistemimiz. Ankara: Ütopya

Okçabol, R.; Akpınar, Y.; Caner, A.; Erktin, E.; Gök, F.; Ünlühisarcıklı, Ö. (2003) Öğretmen yetiştirme araştırması. Ankara: Eğitim-Sen.

Önsoy, R. (1998) Üniversitelerimiz ve öğretmen yetiştirme. Milli Eğitim $139,18-20$

Özdamar, K. (2004) Paket programlar ile istatistiksel veri analizi. Dördüncü Baskı. Eskişehir: Kaan Kitabevi.

Özdemir, S. (1998) Eğitimde örgütsel yenileşme. Üçüncü Baskı. Ankara: Pegem

Özdilek -Kılıç, F. (1997) “İlköğretim okullarına sınıf öğretmeni olarak atanmakta olan adayların öğretmenlik meslek bilgisi düzeyleri ile öğretmenlik mesleğine yönelik tutumları". Yayınlanmamış Yüksek Lisans Tezi. Anadolu Üniversitesi, Sosyal Bilimler Enstitüsü, Eskişehir

Saracaloğlu, A. S. (1991) Fen ve Edebiyat Fakülteleri öğrencilerinin öğretmenlik mesleğine yönelik tutumları. Birinci Ulusal Eğitim Kongresi Bildirileri (pp.565-569) İzmir.

Saracaloğlu, A. S. (1992) Beden eğitimi öğretmeni adaylarının mesleğine yönelik tutumları. Spor Bilimleri Dergisi. 3 (1), 10-26.

Saracaloğlu, A. S.; Bozkurt, N.; Serin, O \& Serin, U. Öğretmen adaylarının mesleğe yönelik tutumlarını etkileyen faktörler. Çağdaş Eğitim. 29 (311); 16-27.

Seferoğlu, S. S. (2004) Öğretmen adaylarının öğretmenliğe yönelik tutumları. XII. Eğitim Bilimleri Kongresi-Bildiriler (Cilt 1) (pp. 413423) Gazi Üniversitesi Eğitim Bilimleri Enstitüsü, Ankara

Shen, J. (1999) The school of education. Its mission, faculty, and reward structure. New York: Peter Lang Publishing Inc.

Soder, R. \& Sirotnik, K.A. (1990) Beyond reinventing the past: The politics of teacher education. In J.I. Goodlad, R. Soder \& K. A. Sirotnik (Eds.) Places Where Teachers Are Taught. (pp. 385-415) San Francisco: Jossey- Bass.

Sözer, E. (1992) Eğitim fakültesi öğrencileri ile öğretmenlik sertifikası programı öğrencilerinin ögretmenlik mesleğine yönelik tutumları. Eskişehir: Anadolu Üniversitesi Yay.

Şişman, M. (2000) Öğretmenliğe giriş. İkinci Baskı. Ankara: Pegem A Yay. 
Tanrı̈ğen, A. (1997) Buca Eğitim Fakültesi öğrencilerinin öğretmenlik mesleğine yönelik tutumları. Pamukkale Üniversitesi Ĕgitim Fakültesi Dergisi. 3 (1), 55-58

Walton, J. (1964) Education as an academic discipline. In M. Gillett \& J. A. Laske (Eds.) Foundation studies in education. (pp. 119-121) Metuchan, NJ: The Scarecrow Press.

Yang, S. (1998) Comparison, understanding and teacher education in international perpective. Frankfurt am Main: Peter Lang.

Yılman, M. \& Dinç, C. (2000) Türkiye'de uygulanmış öğretmen eğitimi programlarının pedagojik formasyon yönünden karşılaştırılması. In. R. C. Akçay \& M. A. Başar (Ed.) II. Ulusal Öğretmen Yetiştirme Seтроzуити. (pp. 234-237) Çanakkale: Onsekiz Mart Üniversitesi Eğitim Fakültesi.

Yükseköğretim Kurulu (YÖK) (1997) 6.10.1997 Tarih ve B.30.0.000.0.01/534-22449 Say1l1 Yazıs1 ve Ekleri.

Yükseköğretim Kurulu (YÖK) (2006) http://www.yok.gov.tr/egitim/ ogretmen/yeni_programlar.htm adresinden 04.08.2006 tarihinde edinildi.

Yüksel, S. (2004a) Eğitim fakültesi öğrencilerinin öğretmenlik meslek bilgisi derslerine yönelik direnç davranışları. Kuram ve Uygulamada Eğitim Bilimleri, 4 (1), 171-200

Yüksel, S. (2004b) Tezsiz yüksek lisans programının öğrencilerin öğretmenlik mesleğine ilişkin tutumlarına etkisi. Uludă̆ Üniversitesi Eğitim Fakültesi Dergisi, 17 (2), 355-379

Zeichner, K. M. (1988) Understanding the character and quality of the academic and professional components of teacher education. ERIC Digest. (ED 301537) 
Ek: Öğretmenlik Meslek Bilgisi Dersleri Ölçeğinde (ÖMBÖ) Yer Alan Maddeler

Faktör 1 ÖMB DERSLERİ

1. Dersler arasında en çok eğitim derslerini severim.

2. Eğitim derslerinin konuları ilgimi çeker.

3. Elimden gelse eğitim derslerine girmek istemem.

4. Eğitim dersleri sevdiğim dersler arasındadır.

5. Bana kalsa bu dersleri programdan kaldırırım.

6. Eğitim derslerini anlamsız ve gereksiz buluyorum.

7. Eğitim derslerinin konuları benim için doyurucudur.

8. Eğitim dersleri bölümdeki diğer alan (branş) dersleri kadar önemli dersler değildir.

9. Eğitim derslerinin konularının azaltılması gerekir.

10.Eğitim derslerini sevmiyorum.

11.Eğitim derslerini isteyerek çalışırım.

12.Eğitim derslerini sıkıcı buluyorum .

13. Ĕgitim derslerine girmek benim için zaman kaybıdır.

14.Eğitim dersleri benim için öncelikli dersler arasında yer almıyor.

15.Eğitim derslerini hayatla ilgili olmayan soyut konular içerdiği için sevmiyorum.

16. Eğitim derslerine mecbur olduğum için çalışırım.

17.Eğitim dersleri çok sönük ve sıkıcı geçmektedir.

18.Eğitim derslerinde saatler geçmek bilmiyor.

19.Eğitim dersleri bittiğinde kendimi yorgun hissederim.

20.Eğitim derslerine gireceğim saati dört gözle beklerim.

21.Eğitim derslerine girerken büyük bir isteksizlik duyarım.

Faktör 2 ÖĞRETMENLİK MESLEĞİ

1. Bu bölümü kazandığım için mecburen öğretmen olacağım.

2. Öğretmen olup olmayacağım konusunda kararsızım. 
3. Öğretmen olmak istemiyorum.

4. Öğretmenlik severek ve isteyerek yapabileceğim bir iştir.

5. Mezun olunca iyi bir iş teklifi alsam hemen öğretmenliği bırakırım.

6. Öğretmenlik mesleğinin beni ne maddi ne de manevi açıdan tatmin edeceğini zannetmiyorum.

7. Öğretmenlik mesleğinden nefret ederim.

8. Gelecekte sürekli bir sınıfta hapsolacağımı düşünmek beni korkutuyor.

9. Bence öğretmenliğin cazip tarafları vardır

Faktör 3 ÖMB ÖĞRETIMM ELEMANLARI

1. Elimden gelse eğitim derslerine giren öğretim elemanlarından ders almam.

2. Eğitim derslerine giren öğretim elemanlarını sevmiyorum.

3. Eğitim derslerine giren öğretim elemanları bana not verirken (beni değerlendirirken) objektif davranmak yerine kişisel inanç, fikir ve tutumlarına göre davranmaktadır.

4. Bana göre eğitim derslerine giren öğretim elemanları derslerini ciddiye almiyorlar.

5. Eğitim derslerine giren öğretim elemanlarının kullandığı öğretim yöntemleri beni motive etmiyor.

6. Eğitim derslerine giren öğretim elemanlarını akademik yönden yeterli bulmam.

7. Eğitim dersine giren öğretim elemanları bizi anlamak istemiyorlar.

8. Eğitim dersine giren öğretim elemanlarıyla iletişim kuramıyorum.

9. Eğitim dersine giren öğretim elemanlarının derste verdikleri örnekler alanımızla ilgili değildir.

Faktör 4 ÖMB DERSLERININ GEREKLİLIĞİ

1. Eğitim derslerinde öğrendiklerimi öğretmenlik yaparken kullanabileceğimi düşünmüyorum.

2. Eğitim dersleri iyi öğretmen olabilmek için gereklidir.

3. Eğitim derslerindeki konularını iyi öğrenirsem iyi bir öğretmen olurum 
